\title{
Pengembangan Media Pembelajaran Trainer Kit Teknik Digital berbasis Cooperative Learning Approach
}

\author{
Ratna Ekawati $^{1]}$, Endi Permata ${ }^{2]}$, Mohammad Fatkhurrohman ${ }^{3]}$, \\ Irwanto $^{4]}$, Siti Afridah ${ }^{5]}$ \\ Universitas Sultan Ageng Tirtayasa \\ E-mail: ${ }^{1]}$ ratnaekawati@untirta.ac.id \\ ${ }^{2]}$ endipermata@untirta.ac.id \\ ${ }^{3]}$ fatkhur0404@untirta.ac.id \\ ${ }^{4]}$ irwanto.ir@untirta.ac.id \\ ${ }^{5]}$ sitiafridah.xiipa1@gmail.com
}

\begin{abstract}
Abstrak
Pembuatan media pembelajaran sangat dibutuhkan untuk media pembelajaran praktik di program studi pendidikan vokasional teknik elektro. Adanya perkembangan industri elektronika yang sangat pesat, kurangnya keefektifan proses praktikum siswa, karena jumlah siswa dalam satu kelas yang mencapai lebih dari 37 tidak sebanding dengan jumlah media pembelajaran yang terbatas disekolah yaitu tiga buah. Adanya pengabungan mata pelajaran pengukuran listrik dan dasar elektronika menjadi mata pelajaran dasar listrik dan elektronika berpengaruh pada pengurangan jam pembelajaran. Sebelum adanya perubahan kurikulum, proses pembelajaran dilakukan selama 10 jam setelah digabung yaitu hanya 5 jam. Penelitian ini bertujuan untuk mengembangkan media pembelajaran trainer kit teknik digital, mengetahui tingkat kelayakan dan keefektifan media pembelajaran teknik digital dalam pembelajaran praktikum di SMK N 2 Kota Serang jurusan teknik ketenagalistrikan pada materi gerbang logika dasar. Metode yang digunakan dalam penelitian ini adalah R\&D prosedur penelitian pengembangan media mengadaptasi dari langkah yang ditulis oleh Sukmadinata. Tahap-tahap penelitian pengembangan yang telah dimodifikasi terdiri dari studi pendahuluan, pengembangan produk dan uji produk. Data hasil pengujian terhadap siswa didapatkan data kelayakan media pembelajaran dengan perolehan rata-rata skor sebesar 87,7 terletak pada interval $\mathrm{x} \geq 75$. Hasil rata-rata skor tersebut dapat disimpulkan bahwa media pembelajaran trainer teknik digital dikategorikan sangat layak. Hasil keseluruhan dari masing-masing evaluasi penilaian diperoleh persentase sebesar $89 \%$ dengan kategori baik yang berarti penggunaan media pembelajaran trainer teknik digital dapat dikategorikan efektif dalam pembelajaran. Jadi dapat disimpulkan bahwa media pembelajaran trainer kit teknik digital sangat layak digunakan sebagai media pembelajaran di program studi pendidikan vokasional teknik elektro untuk mata kuliah teknik digital.
\end{abstract}

Kata kunci: Trainer Kit, Gerbang Logika Dasar, Pengembangan 


\title{
Development of Digital Engineering Trainer Kit Learning Media based on Cooperative Learning Approach
}

\begin{abstract}
Making learning media is very much needed for practical learning media in electrical engineering vocational education study programs. The existence of a very rapid development of the electronics industry, lacks the effectiveness of the student practicum process, because the number of students in one class that reaches more than 37 is not proportional to the limited number of learning media in schools, namely three. The merging of electrical measurement subjects and basic electronics into basic electricity and electronics subjects has an effect on reducing learning hours. Prior to the curriculum change, the learning process was carried out for 10 hours after being merged, which was only 5 hours. This study aims to develop a digital engineering trainer kit learning media, to find out exactly and the effectiveness of digital engineering learning media in practical learning at SMK N 2 Serang City majoring in electrical engineering on logic logic material. The method used in this research is the $R \& D$ procedure of media development research that adapts the steps written by Sukmadinata. The stages of research and development consist of preliminary studies, product development and product testing. The results of data testing on students obtained learning media data with an average score of 87.7 located at the interval $x$ 75. The results of the average score, learning media, digital techniques can be categorized as very feasible. The overall results of each assessment evaluation were obtained by $89 \%$ with a good category, which means that the use of digital technique trainer learning media can be effective in learning. So it can be said that the digital engineering trainer kit learning media is very suitable to be used as a learning medium for the electrical engineering education study program for digital engineering courses.
\end{abstract}

Keywords: Trainer Kit, Basic Logic Gate, Development

\section{PENDAHULUAN}

Sebagai salah satu lembaga yang menyelenggarakan pendidikan secara formal, sekolah memiliki peranan yang sangat penting dalam mewujudkan tujuan endidikan nasional melalui proses belajar mengajar. Pada UU NO. 20 Tahun 2003 Pasal 3 menyatakan bahwa: fungsi dari pendidikan nasional adalah mengembangkan kemampuan dan membentuk watak serta peradaban bangsa yang bermanfaat dalam rangka mencerdaskan kehidupan bangsa, untuk mengembangkan potensi peserta didik agar menjadi manusia yang beriman dan bertaqwa pada Tuhan Yang Maha Esa, berakhlak mulia, sehat berilmu, cakap, kreatif, mandiri dan menjadi warga yang demokratis dan bertanggung jawab.

Pendidikan mempunyai peranan yang penting dalam kehidupan manusia, dengan pendidikan manusia dapat belajar dan membentuk karakter diri yang kemudian digunakan untuk berinteraksi dengan manusia lainya di sekitarnya. Pendidikan merupakan proses belajar tiada henti yang berjalan seumur hidup. Pendidikan menjadikan seorang manusia siap untuk berinteraksi dan menghadapi perubahan-perubahan yang terjadi di masyarakat. Pendidikan juga menjadi salah satu tolak ukur untuk mengukur kualitas sumber daya manusia yang ada di dalam suatu bangsa. 
Semakin berkualitas pendidikan sebuah bangsa, maka semakin banyak manusia cerdas dan berkualitas yang dihasilkan. Pada abad ke-21 pendidikan khususnya pada vokasi dituntut agar peserta didik mampu menguasai kompetensi berbasis industri (Wijaya, dkk, 2018).

Dengan adanya UU No. 20 Tahun 2003 untuk mewujudkan tujuan pendidikan nasional yang sesuai dengan kurikulum pada lembaga pendidikan formal, dalam proses belajar mengajar. Menteri Perindustrian yaitu Airlangga Hartanto mengeluarkan Peraturan Menteri Perindustrian (Permenperin) Nomor 3 tahun 2017 yang berisi tentang Pedoman Pembinaan dan Pengembangan Sekolah Menengah Kejuruan (SMK) yang berbasis kompetensi yang link and match dengan Industri. Dalam Permenperin tersebut, dijelaskan tentang peran SMK, antara lain melakukan penyusunan kurikulum yang mengacu pada Standar Kompetensi Kerja Nasional Indonesia (SKKNI) atau standar internasional yang meliputi: (1) aspek pengetahuan; (2) aspek keterampilan; (3) aspek keahlian; dan (4) aspek sikap kerja yang baik, upaya ini akan melibatkan pelaku dan asosiasi industri. Selanjutnya, SMK perlu menyediakan kebutuhan minimum sarana dan prasarana praktikum seperti workshop dan laboratorium, serta pemenuhan kebutuhan guru bidang studi produktif (Kemenperin, 2017).

Lulusan yang kompeten hanya dapat dihasilkan dari suatu proses yang didukung komponen-komponen penunjang yang sesuai, antara lain daya dukung peralatan yang ada di laboratorium. Sudira (2011) menyatakan pengalaman belajar peserta didik sangat dipengaruhi oleh sarana dan prasarana belajar (learning resources equipment), susasana akademik, penampilan guru/dosen, lingkungan belajar serta perangkat ICT. Sarana praktik di Universitas khususnya Fakultas Keguruan dan Ilmu Pendidikan merupakan syarat utama untuk menunjang kelancaran proses pembelajaran. Salah satu sarana terpenting dalam pembelajaran praktik yaitu media pembelajaran (trainer).

Trainer atau alat peraga merupakan salah satu media pembelajaran yang mengandung atau membawakan ciri-ciri dari konsep yang dipelajari oleh peserta didik dalam proses pembelajaran (Sudjana, 2015). Dengan adanya trainer peserta didik tidak hanya dituntut untuk mengingat dan melihat job yang ada tetapi juga langsung mempraktikan/membuat rangkaian dari job tersebut, sehingga peserta didik lebih memahami materi tersebut. Hal itu sesuai dengan hasil penelitian lembaga riset dan penerbitan komputer yaitu Computer Technology Research (CTR) dalam Susanto (2013) menyatakan bahwa orang hanya mampu mengingat $20 \%$ dari yang dilihat dan $30 \%$ dari yang didengar. Tetapi orang dapat mengingat $50 \%$ dari yang dilihat dan didengar, serta $80 \%$ dari yang dilihat, didengar, dan dilakukan sekaligus. Didukung oleh penelitian Muti'ah (2017) menyatakan bahwa trainer dapat membantu dan mempermudah pengajar maupun peserta didik dalam melakukan pembelajaran praktikum.

Sistem pendidikan nasional dalam UU No. 20 Tahun 2003 menyebutkan bahwa kurikulum adalah seperangkat rencana dan pengaturan mengenai tujuan, isi dan bahan pelajar serta cara yang digunakan sebagai pedoman penyelenggaraan kegiatan pembelajaran untuk mencapai tujuan pendidikan. Sedangkan, dalam pengembangan kurikulum KTSP menjadi Kurikulum 2013 bertujuan untuk mempersiapkan agar sekolah mampu memberi waktu yang cukup dalam mengembangkan sikap, pengetahuan dan keterampilan. (Kemendikbud, 2016). Berdasarkan observasi yang dilakukan di SMK N 2 
Kota Serang, penerapan perubahan kurikulum dari KTSP menjadi Kurikulum 2013 merupakan salah satu kendala yang terjadi di SMK N 2 Kota Serang. Salah satunya adalah penerapan dalam mata pelajaran baru yaitu dasar listrik dan elektronika. Guru harus dapat mengikuti kurikulum 2013 yang berlaku disekolah agar pembelajaran pada mata pelajaran dapat terlaksana dengan baik dan pembelajaran praktikum dapat lebih efektif. Sedangkan, Minimnya media pembelajaran teknik digital sebagai penunjang mata pelajaran dasar listrik dan elektronika merupakan kendala yang sering dihadapi Sekolah Menengah Kejuruan (SMK) khususnya jurusan teknik ketenagalistrikan, seperti yang ada di SMK N 2 Kota Serang. Sekolah Menengah Kejuruan (SMK) dituntut agar lulusan mempunyai kompetensi yang handal dalam bidangnya (Kemendikbud, 2016). Sedangkan, untuk memenuhi kompetensi yang sudah ditetapkan dalam silabus, sekolah perlu mengeluarkan biaya yang cukup banyak untuk pengadaan alat atau bahan praktikum.

Dengan adanya perkembangan industri elektronika yang sangat pesat, seyogianya SMK program keahlian teknik ketenagalistrikan mencari atau membuat media pembelajaran yang mendukung proses pembelajaran. Seperti halnya dasar listrik dan elektronika yang merupakan salah satu mata pelajaran yang harus dipelajari siswa SMK program keahlian teknik ketenagalistrikan. Bagi siswa, mereka berupaya mengerti dan memahami materi gerbang logika dasar dalam mata pelajaran dasar listrik dan elektronika secara praktis. Pemahaman yang dipelajarai tentang gerbang logika dasar, penyederhanaan persamaan, pemahaman mengenai fungsi dan cara kerja dari IC gerbang logika.

Menurut informasi dari hasil wawancara dengan guru di jurusan teknik ketenagalistrikan SMK N 2 Kota Serang, diperoleh bahwa trainer kit media pembelajaran teknik digital yang tersedia di sekolah hanya terbatas yaitu berjumlah tiga buah dalam bentuk trainer papan dan bentuk box besi yang kurang flexsible. Beberapa komponen penting pada trainer tersebut telah hilang dan rusak. Sehingga, trainer yang akan dikembangkan akan dibuat lebih flexsible dalam penggunaanya dan dibuat dalam bentuk koper dilengkapi dengan komponen yang akan lebih flexsible. Karena terbatasnya jumlah trainer disekolah berarti, media pembelajaran ini belum mencukupi untuk digunakan sebagai media pembelajaran praktikum. Sehingga, guru jarang menggunakan trainer dalam pembelajaran praktikum karena terbatasnya media dan dapat menyita waktu pembelajaran. Oleh karena itu, banyak siswa yang cenderung kurang memahami materi teknik digital. Hal ini dapat dibuktikan dengan persentase nilai siswa kelas X TL 6 pada tahun ajaran 2015-2016 yang hanya mencapai batas KKM yaitu >75-85 dengan persentase $30 \%$ dari jumlah siswa yang ada pada satu kelas pada tahun 2016. Sedangkan, “Tingkat keberhasilan pembelajaran dapat dikatakan kurang yaitu apabila bahan pembelajaran yang telah disampaikan kurang $75 \%$ dikuasai oleh siswa (Sutikno dkk, 2015) ini berarti tingkat keberhasilan pembelajaran di SMK N 2 Kota Serang dapat dikatakan kurang dengan persentase siswa yang mencapai KKM hanya $30 \%$ dalam mata pelajaran dasar listrik dan elektronika pada materi gerbang logika dasar.

Kurangnya keefektifan proses praktikum siswa, karena jumlah siswa dalam satu kelas yang mencapai lebih dari 37 tidak sebanding dengan jumlah media pembelajaran yang terbatas disekolah yaitu tiga buah. Adanya pengabungan mata pelajaran pengukuran listrik dan dasar elektronika menjadi 
mata pelajaran dasar listrik dan elektronika berpengaruh pada pengurangan jam pembelajaran. Sebelum adanya perubahan kurikulum, proses pembelajaran dilakukan selama 10 jam setelah digabung yaitu hanya 5 jam. Hal ini menjadi salah satu kendala yang terjadi dalam keefektifan proses pembelajaran praktikum. Karena penggabungan mata pembelajaran pengukuran listrik dan dasar elektronika, serta pengurangan waktu kegiatan belajar mengajar. Permasalahan ini merupakan salah satu kendala yang dihadapi guru dalam pembelajaran praktik. Sehingga, perlunya dibuat media yang dapat menunjang pembelajaran teknik digital. Karena terbatasnya media pembelajaran teknik digital yang tersedia dan untuk meningkatkan keefektifan pembelajaran praktik pada siswa.

Praktik teknik digital menggunakan jobsheet sebagai lembar kerja mahasiswa dalam melakukan pembelajaran. Berdasarkan observasi yang telah dijelaskan pada bab sebelumnya, jobsheet perlu dikembangkan untuk merangsang motivasi mahasiswa dalam melakukan praktikum. Selain jobsheet media cetak dalam penelitian ini adalah user manual. Jobsheet merupakan salah satu media dalam kegiatan instruksional yang digunakan untuk membantu proses belajar mengajar pada praktikum

Evaluasi dalam pengembangan media pembelajaran ini menggunakan evaluasi formatif. Penelitian ini menggunakan evaluasi satu lawan satu dan evaluasi lapangan. Tahap evaluasi satu lawan satu dan evaluasi lapangan. Tahap evaluasi satu lawan satu media pembelajaran ini dievaluasikan kepada ahli mediadan ahli materi yang terdiri dari dosen dan guru, sedangkan evaluasi lapangan diujikan ke sejumlah siswa. Hasil evaluasi dari para evaluator menjadi dasar pertimbangan dilakukan perbaikan media pembelajaran.
Terbatasnya fasilitas dan peralatan pendukung dalam pembelajaran menyebabkan siswa kurang tertarik dan kesulitan dalam memahami mata pelajaran dasar listrik dan elektronika. Oleh karena itu, diperlukan suatu media atau perangkat yang lengkap dan dapat memenuhi kebutuhan pembelajaran siswa guna meningkatkan keaktifan siswa di kelas dan membantu siswa memahami materi teknik digital dalam mata pelajaran dasar listrik dan elektronika.

Berdasarkan uraian di atas, penulis tertarik membuat suatu media pembelajaran yang dapat digunakan sebagai trainer yang berisikan rangkaian gerbang logika dasar dari IC TTL 74xx. Trainer ini dapat digunakan dalam pengaplikasian dan menyelesaikan persoalan-persoalan dalam materi teknik digital seperti membuat rangkaian gerbang logika dasar, rangkaian sekuensial dan kombinansional. Trainer ini dikemas dalam sebuah case atau koper yang berukuran $370 \mathrm{~mm}$ x 250 $\mathrm{mm} \times 120 \mathrm{~mm}$.

Berdasarkan uraian di atas, penulis tertarik untuk mengembangkan Trainer Teknik Digital sebagai media pembelajaran pada mata kuliah Praktik Teknik Digital dan dilengkapi dengan jobsheet serta buku user manual nya. Media Praktik yang dimaksud berupa trainer yang terdiri dari beberapa bagian yaitu input, output, dan papan rangkaian dan jobsheet yang secara garis besar berisi tujuan, uraian materi, permasalahan, langkah praktik, dan penugasan. Trainer Teknik Digital ini diharapkan dapat membantu proses pembelajaran untuk meningkatkan kompetensi dan keaktifan mahasiswa elektronika dalam mengeksplorasi teknik digital (Aggarwal, Er, H., Saini, R., \& Singh, S, 2015).

Berdasarkan permasalahan yang dirumuskan diatas, tujuan penelitian ini 
yaitu: (1) Mengembangkan media pembelajaran Teknik digital di SMK N 2 Kota Serang jurusan teknik ketenagalistrikan pada mata pelajaran dasar listrik dan elektronika; (2) Mengetahui tingkat kelayakan media pembelajaran trainer kit teknik digital di SMK N 2 Kota Serang jurusan teknik ketenagalistrikan; (3) Mengetahui tingkat keefektifan pembelajaran praktikum dengan menggunakan media pembelajaran trainer di SMK N 2 Kota Serang jurusan teknik ketenagalistrikan.

\section{METODE}

Penelitian yang dilakukan peneliti merupakan jenis penelitian pengembangan atau Research and Development (R\&D). Menurut Sugiyono (2011), metode penelitian R\&D adalah metode penelitian yang digunakan untuk menghasilkan produk tertentu, dan menguji keefektifan produk tersebut. Sukmadinata (2012) mendefinisikan penelitian R\&D adalah suatu proses atau langkah-langkah untuk mengembangkan suatu produk baru atau menyempurnakan produk yang telah ada, yang dapat dipertanggungjawabkan. Penelitian pengembangan merupakan suatu penelitian yang menghasilkan suatu produk, misalnya trainer, buku, jobsheet, modul pembelajaran, LKS siswa, kurikulum pengembangan, model pembelajaran (Irwanto, 2020).

Langkah-langkah pengembangan yang dipilih peneliti mengacu pada sepuluh langkah pelaksanaan strategi penelitian dan pengembangan menurut Borg dan Gall dalam Sukmadinata (2012) adalah sebagai berikut:

1. Penelitian dan pengumpulan data (research and information collecting). Pengukuran kebutuhan, studi literatur, penelitian dalam skala kecil dan pertimbangan-pertimbangan dari segi nilai.

2. Perencanaan (planning). Menyusun rencana penelitian, meliputi kemampuan- kemampuan yang diperlukan pelaksanaan penelitian, rumusan tujuan yang hendak dicapai dengan penelitian tersebut, desain atau langkah-langkah penelitian, kemungkinan pengujian dalam lingkup terbatas.

3. Pengembangan draf produk (develop preliminary from of product). Pengembangan bahan pembelajaran, proses pembelajaran dan instrumen evaluasi.

4. Uji coba lapangan awal (preliminary field testing). Uji coba dilapangan pada 1 sampai 3 sekolah dengan 6 sampai dengan 12 subjek uji coba (guru). Selama uji coba diadakan pengamatan, wawancara dan pengedaran angket.

5. Merevisi hasil uji coba (main product revision). Memperbaiki atau menyempurnakan hasil uji coba.

6. Uji coba lapangan (main filed testing). Melakukan uji coba yang luas pada 5 sampai dengan 15 sekolah dengan 30 sampai dengan 100 orang subjek uji coba. Data kuantitatif penampilan guru sebelum dan sesudah menggunakan model yang dicobakan dikumpulkan. Hasilhasil pengumpulan data dievaluasi dan kalau mungkin dibandingkan dengan kelompok pembanding.

7. Penyempurnaan produk hasil uji lapangan (operational product revision). Menyempurnakan produk hasil uji lapangan.

8. Uji pelaksanaan lapangan (operational field testing). Dilaksanakan pada 10 sampai dengan 30 sekolah melibatkan 40 sampai dengan 200 subjek. Pengujian dilakukan melalui angket, wawancara, dan observasi dan analisis hasilnya.

9. Penyempurnaan produk akhir (final product revision). Penyempurnaan didasarkan masukan dari uji pelaksanaan lapangan.

10. Diseminasi dan implementasi (dissemination and implementation). Melaporkan hasilnya dalam pertemuan 
profesional dan dalam jurnal. Bekerjasama dengan penerbit untuk penerbitan. Memonitor penyebaran untuk pengontrolan kualitas.

Dari kesepuluh tahapan tersebut, peneliti melakukan penyederhanaan tahapan. Penyederhanaan tahapan ini didasari oleh pendapat Borg \& Gall dalam Emzir (2011) yang menyarankan untuk membatasi penelitian dalam skala kecil, termasuk kemungkinan untuk membatasi langkah penelitian. Penyederhanaan tahapan penelitiandilakukan oleh peneliti dikarenakan keterbatasan waktu dan biaya yang dimiliki oleh peneliti.

Prosedur penelitian pengembangan media mengadaptasi dari langkah yang ditulis oleh Sukmadinata. Menurut Sukmadinata (2012) tahap-tahap penelitian pengembangan yang telah dimodifikasi dimulai dari: (1) studi pendahuluan; (2) pengembangan produk; (3) uji coba produk. Gambar 1. merupakan langkah-langkah pengembangan menurut Sukmadinata, sebagai berikut.

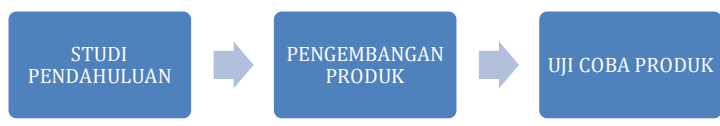

Gambar 1. Tahapan $R \& D$

Subyek penelitian pengembangan ini adalah peserta didik kelas X TL 6 di SMK N 2 Kota Serang Jurusan Teknik Ketenagalistrikan yang mengambil mata pelajaran dasar listrik dan elektronika sebanyak 30 siswa.

Teknik analisis data pada penelitian ini adalah menggunakan deskriptif kualitatif, yaitu memaparkan hasil produk media yang telah dirancangan setelah diimplementasikan dalam bentuk produk jadi dan melakukan uji tingkat kelayakan produk serta keefektifan produk.

Penelitian ini merupakan penelitian pengembangan Research and Development (R\&D) dengan 10 tahapan prosedur meliputi: 1) Potensi dan masalah,
2) Pengumpulan data, 3) Desain produk, 4) Validasi desain, 5) Revisi desain, 6) Ujicoba produk, 7) Revisi produk, 8) Ujicoba pemakaian, 9) Revisi produk , dan 10) Produksi masal. Tahapan awal penelitian adalah perancangan yang dilakukan sesuai dengan prosedur pengembangan. Setelah perancangan selesai untuk memperoleh tingkat kelayakan media pembelajaran dilakukan uji kelayakan. Uji kelayakan dilakukan agar media pembelajaran sesuai dengan tujuan pemecahan masalah. Uji kelayakan tersebut terdiri dari uji validasi materi dan media ahli dan media oleh pakar ahli serta uji pemakaian oleh mahasiswa. Dari proses inilah sebuah pengembangan Trainer Teknik Digital diharapkan dapat dijadikan media pembelajaran sehingga akan meningkatkan kualitas pembelajaran pada Mata Kuliah Praktik Teknik Digital FKIP Universitas Sultan Ageng Tirtayasa.

Teknik analisis data yang dipergunakan pada tahap pertama adalah menggunakan deskriptif kualitatif, yaitu memaparkan produk media hasil rancangan setelah diimplementasikan dalam bentuk produk jadi serta menguji tingkat kelayakan sebuah produk. Deskriptif kualitatif ini juga digunakan peneliti dalam menganalisis hasil observasi permasalahan pembelajaran Praktik Teknik Digital.

Tahap kedua menggunakan deksriptif kuantitatif yaitu mengenai paparan terkait tingkat kelayakan produk. Tingkat kelayakan ini diperoleh dari data kuisioner penelitian yang diberikan kepada ahli materi dan ahli media (experts judgment) dan siswa. Data tersebut masih berupa data kualitatif, sehingga perlu dikonversi menjadi data kuantitatif dengan tingkatan bobot nilai. Tingkatan pembobotan nilai menggunakan skala likert $(4,3,2,1)$. 


\section{HASIL DAN PEMBAHASAN}

Belajar Elektronika, khususnya Teknik Digital merupakan belajar yang dalam penyampaiannya memerlukan halhal yang konkret, sehingga siswa akan lebih mudah dalam memahami materi yang diajarkan. Oleh karena itu, dalam proses belajar mengajar guru memerlukan media yang mampu menjadi alat bantu siswa dalam belajar. Media bantu yang dimaksud adalah trainer komponen yang sudah tertata sehingga siswa mengetahui cara perangkaian model sederhana. Pembelajaran teknik digital dapat mencapai sasaran melalui model, metode dan media pembelajaran yang tepat yang digunakan oleh guru. Melalui model pembelajaran langsung, guru bisa mengontrol urutan dan keluasan materi pembelajaran, dengan demikian guru dapat mengetahui sejauh mana siswa menguasai bahan pelajaran yang disampaikan. Model pembelajaran langsung dengan sangat efektif apabila materi pelajaran yang harus dikuasai siswa cukup luas, sementara itu waktu yang dimiliki untuk belajar terbatas. Berdasarkan hal tersebut maka dapat dikemukakan bahwa tantangan pembelajaran saat ini adalah perlunya mengembangkan perangkat pembelajaran menggunakan trainer kit pada pelajaran Teknik Digital di SMK N 2 Kota Serang.

Maka dapat ditarik kesimpulan bahwa guru yang paling bertanggung jawab atas ketidakberhasilan tamatan dalam memenuhi standar kelulusan tamatan, walaupun terdapat faktor lain yang mempengaruhinya. Hal tersebut mendorong peneliti untuk mengamati pembelajaran yang berlangsung khususnya mata pelajaran Teknik Digital.

Media bantu yang dimaksud adalah trainer yang sudah dibedah sehingga siswa mengetahui sistem yang ada di dalamnya. Pembelajaran Trainer Kit dapat mencapai sasaran melalui model, metode dan media pembelajaran yang tepat yang digunakan oleh guru. Sebagai sekolah kejuruan yang berorientasi pada teori dan praktik maka model pembelajaran yang tepat adalah model pembelajaran langsung dengan metode demonstrasi. Model pembelajaran langsung tepat digunakan dalam pembelajaran teknik digital karena guru mempersiapkan dan melaksanakan pelatihan dan mendemonstrasikan kegiatan praktik yang dikombinasikan dengan latihan.

Berdasarkan hasil uji validitas dan uji pemakaian produk yang telah dikembangkan diperoleh hasil penelitian sebagai berikut.

\section{a. Pengembangan Media}

Penelitian dan pengembangan media pembelajaran trainer teknik digital ini dilatar belakangi oleh permasalahanpermasalahan yang telah disebutkan. Tujuan dari pembuatan trainer ini adalah untuk mempermudah siswa dalam mempelajari konsep gerbang logika dasar dan mempermudah guru dalam proses pembelajaran dikelas. Penelitian pengembangan media pembelajaran ini dikembangkan dengan menggunakan metode R\&D model sukmadinata, tahapan penelitian pengembangan menurut sukmadinata yaitu: (1) Studi Pendahuluan, (2) Pengembangan Produk, dan (3) Uji Coba Produk. Tahap pertama yaitu studi pendahuluan yang meliputi beberapa tahapan seperti: (1) Studi Pustaka, (2) Survai Lapangan, dan (3) penyusunan produk awal. Studi pustaka dilakukan dengan mengkaji kurikulum, silabus dan materi pelajaran pada buku yang digunakan sekolah. Tahap berikutnya adalah survai lapangan dilakukan dengan cara observasi dan wawancara mengenai sarana dan prasarana langsung ke sekolah jurusan teknik Ketenagalistrikan dan guru bidang studi dasar pengukuran listrik dan elektronika. Tahap selanjutnya adalah penyusunan produk awal mulai dari 
konsepan bentuk trainer yang akan dikembangkan hingga materi jobsheet yang akan digunakan pada penelitian.

Tahap kedua yaitu, pengembangan produk ini meliputi beberapa tahap seperti: (1) Mendesain produk, tahap ini merupakan penerapan hasil dari observasi potensi dan masalah di SMKN 2 Kota Serang pada mata pelajaran dasar pengukuran listrik dan elektronika. Trainer teknik digital dirancang berdasarkan kebutuhan penunjang pembelajaran dasar pengukuran listrik dan elektronika. Mendesain produk dilakukan dengan cara membuat Hardware dan membuat jobsheet. Pengujian produk dilakukan pada keseluruhan hardware yang telah dibuat untuk menguji kinerja masing-masing komponen. Trainer ini dibuat dalam satu box koper yang terdiri dari box bagian atas dan box bagian bawah, bagian-bagian box terdiri dari beberapa blok yaitu: (a) Blok Input Switch, (b) Blok Rangkaian Gerbang Logika, (c) Blok Output LED, (d) Blok Project Board (e) Blok Power Supply, (f) Blok Socket IC 14 Pin, (g) Blok Socket IC 16 PIN dan (h) Blok Seven Segment. (2) Pengujian produk dalam penggunaan trainer, media pembelajaran ini dilengkapi dengan jobsheet yang disusun sesuai dengan materi tentang pengenalan gerbang logika dasar, gambar rangkaian dari gerbang logika dasar dan rangkaian kombinasi gerbang logika.

Untuk mencapai pembelajara yang efektif dan efisien maka perlu adanya media pembelajaran. Dengan adanya media pembelajaran diharapkan mampu memperjelas dalam penyampaian materi dan memberikan rangsangan yang sama sehingga mampu memudahkan siswa dalam belajar. Keterbatasan media pembelajaran pada mata kuliah Praktik Teknik Digital menyebabkan terhambatnya tujuan pembelajaran. Melihat dari permasalahan tersebut perlu adanya peningkatan media pembelajaran dalam bentuk trainer. Berdasarkan hasil studi lapangan peneliti menyatakan bahwa pada mata kuliah Praktik Teknik Digital: 1) media pembelajaran mata kuliah Praktik Teknik Digital hanya menampilkan simulasi sehingga pemahaman mahasiswa mengenai penerapan teknik digital belum dapat dipraktikan dan 2) media belum mencerminkan dengan pengaplikasian teknik digital dalam industri.

Tahap ketiga yaitu, uji coba produk pada tahap ini meliputi uji validasi kelayakan media oleh ahli materi dan ahli media. Produk yang telah divalidasi dan dikatakan layak kemudian direvisi, setelah itu hasil dari revisi produk dapat di uji cobakan pada siswa. Tahap revisi dilakukan dengan uji kelayakan oleh ahli media dan ahli materi. Tahap selanjutnya adalah uji kelayakan media oleh siswa dan uji keefektifan media pembelajaran trainer kit teknik digital.

\section{b. Kelayakan Media Ditinjau dari Ahli Media dan Ahli Materi}

Tingkat kelayakan media pembelajaran ini dapat dilihat dari hasil ahli materi dan ahli media yang berdasarkan pada penilaian validasi isi (content validity), validasi konstrak (construk validity) dan validasi uji coba pemakaian. Dalam uji kelayakan suatu media trainer kit teknik digital sangat penting untuk mengetahui apakah media pembelajaran tersebut layak digunakan atau tidak. Jadi dalam pengembangan ini, diharuskan menggunakan uji kelayakan media dan uji kelayakan materi serta uji pengguna responden, dimana uji responden ini adalah siswa SMK N 2 Kota Serang.

Instrumen yang diujicobakan berupa bentuk fisik dan unjuk kerja dari media yang akan digunakan dalam proses pembelajaran. Dalam pengujian media pembelajaran, para ahli 
memberikan saran terhadap media pembelajaran yang digunakan untuk bahan revisi produk. Hasil dari uji coba ahli media dapat dilihat pada Lampiran (3). Berikut ini adalah saran yang diberikan oleh ahli media: (1) Sebaiknya instrument Ahli media Lebih fokus keada medianya berkaitan dengan pemilihan komponen, tata letak, kejelasan informasi,warna latarbelakang dan lainlain terkait dengan media. (2) Aspekaspek yang tidak terkait dengan media tidak perlu ditunjukan.

Instrumen yang diujicobakan berupa modul pembelajaran yang berisikan materi-materi yang terdapat pada media pembelajaran. Dalam pengujian materi pembelajaran, para ahli memberikan saran terhadap materi pembeljaran yang digunakan untuk bahan revisi produk.

\section{c. Penilaian Ahli Materi}

Penilaian ahli materi dilakukan oleh dua dosen ahli pendidikan teknik elektro dan dua guru jurusan teknik Ketenagalistrikan. Aspek penilaian pada ahli materi berdasarkan aspek edukatif, skor penilaian ahli materi dapat dilihat pada Gambar 2 berikut ini.

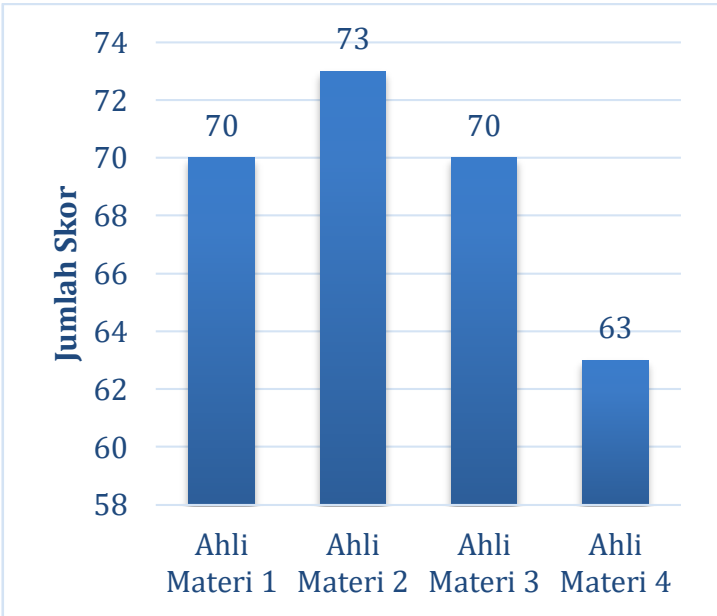

Gambar 2. Hasil validasi ahli materi

\section{d. Penilaian Ahli Media}

Penilaian ahli media dilakukan oleh dua dosen ahli pendidikan teknik elektro dan satu guru jurusan teknik Ketenagalistrikan. Aspek penilaian pada ahli materi berdasarkan aspek teknis dan aspek estetika, skor penilaian ahli media dapat dilihat pada Gambar 3 berikut ini.

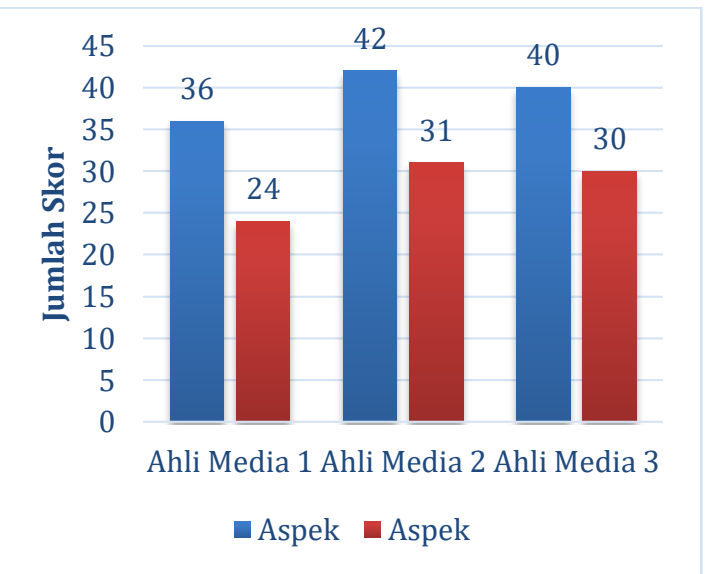

Gambar 3. Hasil validasi ahli media

Berdasarkan data pada Gambar 3 maka diperoleh kategori kelayakan ahli media dari aspek teknis dan estetika dengan Hasil dari presentase ketiga ahli media kemudian diperoleh rerata skor untuk mengetahui kelayakan dari ahli media dengan hasil sebesar 67,7 seperti diperlihatkan pada Gambar 4 di bawah ini.

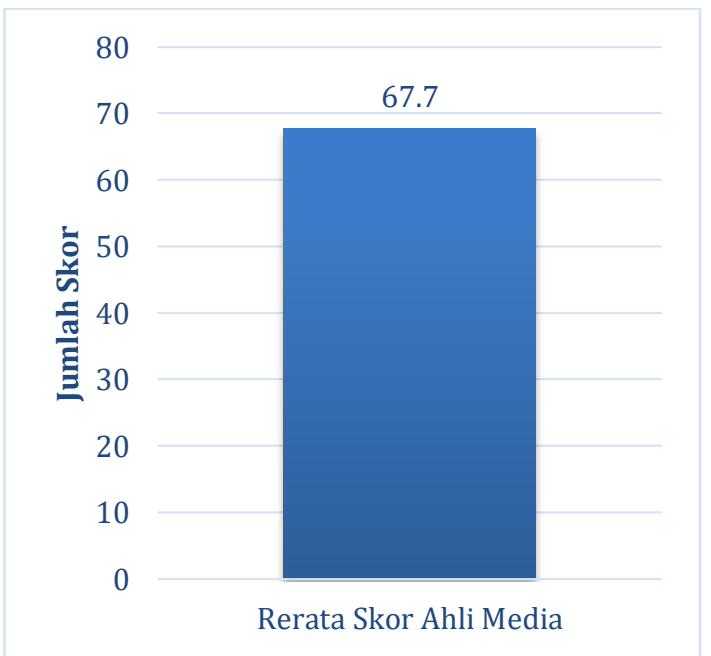

Gambar 4. Hasil validasi ahli media 
Berdasarkan Gambar 4, dapat dilihat bahwa data hasil pengujian didapatkan data kelayakan media pembelajaran sebesar 67,7 yang terletak pada interval $\mathrm{x}$ $\geq 57$, menurut kategori penilaian pada Djemari Mardapi (2017) media pembelajaran ini dikategorikan sangat layak.

\section{e. Uji Produk oleh Siswa Terhadap Media Pembelajaran Sebagai Pengguna}

Media pembelajaran trainer kit teknik digital ini dilakukan pengujian ahir pada siswa SMKN 2 Kota Serang kelas X program keahlian teknik Ketenagalistrikan sejumlah 30 siswa. Pada uji pengguna ini dilakukan penilaian terhadap kelayakan dan kefektifan penggunaan media pembelajaran trainer teknik digital, berikut ini merupakan penjelasan dari masing-masing penilaian kelayakan dan kefektifan media.

Tabel 1. Penilaian media oleh pengguna

\begin{tabular}{cccc}
\hline No & Aspek & Skor Max & Rerata Skor \\
\hline 1 & Edukatif & 32 & 27,3 \\
2 & Teknis & 32 & 27,9 \\
3 & Estetika & 36 & 32,3 \\
\multicolumn{2}{l}{ Rerata Skor } & 100 & 87,7 \\
\hline
\end{tabular}

Pada Tabel 1, dapat dilihat bahwa hasil skor tiap aspek yaitu untuk aspek edukatif dengan skor max 32 dan nilai rata-rata skor dengan nilai 27,3. Sedangkan aspek teknik dengan skor 32 serta reratanya 27,9 dan aspek estetika dengan skor max 36 dengan nilai rerata 32,3. Dari sinilah dapat dikatakan bahwa media ini sangat layak digunakan sebagai media pembelajaran trainer kit teknik digital.

\section{f. Kelayakan Media Ditinjau dari Aspek Materi}

Berdasarkan penilaian pengguna yang berjumlah 9 butir soal yang diberikan pada 30 siswa sebagai responden diperolah hasil penilaian dari Gambar 5 aspek edukatif sebesar 27,3.

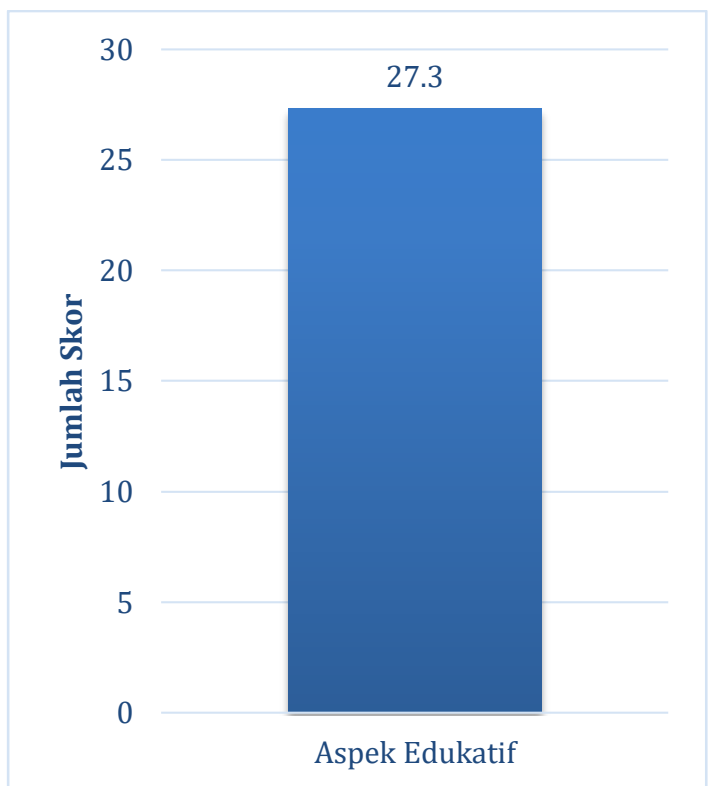

Gambar 5. Rerata aspek edukatif

\section{g. Kelayakan Media Ditinjau dari Aspek Media}

Berdasarkan penilaian pengguna yang berjumlah 9 butir soal untuk aspek teknis dan 10 butir soal untuk aspek estetika yang diberikan pada 30 siswa sebagai responden diperolah hasil penilaian dari Tabel 1 aspek teknis sebesar 27,9. Sedangkan pada aspek estetika rerata presentase diperoleh hasil sebesar 32,3.

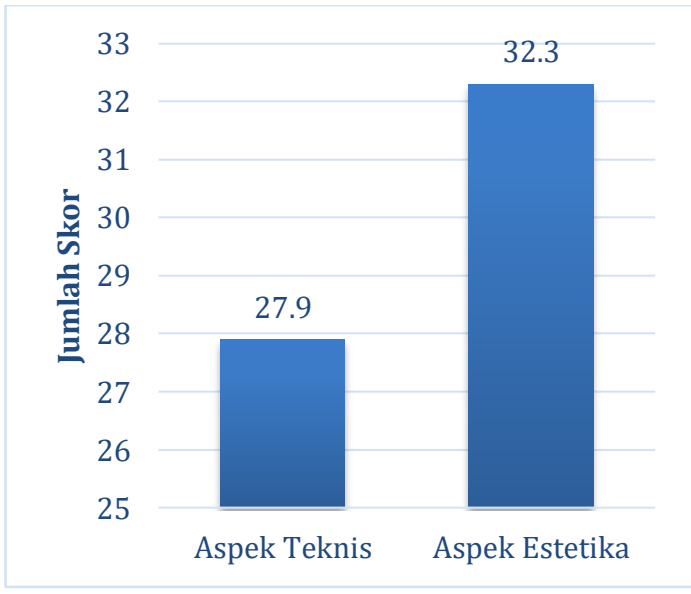

Gambar 6. Rerata teknis dan estetika 
Rerata skor kelayakan media dari aspek edukatif diperoleh hasil sebesar 27,3, aspek teknis memperoleh hasil sebesar 27,9 dan aspek estetika diperoleh hasil sebesar 32,3. Dengan demikian hasil keseluruhan rerata pada kelayakan media yang diujikan pada pengguna adalah 87,7. Berdasarkan data hasil pengujian didapatkan data kelayakan media pembelajaran sebesar 87,7 yang terletak pada interval $\mathrm{x} \geq 75$, menurut kategori penilaian pada Djemari Mardapi (2017) media pembelajaran ini dikategorikan sangat layak.

\section{h. Kefektifan Media}

Berdasarkan hasil tes evaluasi lembar percobaan yang diberikan pada 30 siswa berjumlah 22 butir soal yang terdiri dari lembar percobaan gerbang logika NOT, gerbang logika AND, gerbang logika OR, gerbang logika NAND, gerbang NOR dan gerbang X-OR. Hasil penilaian dari Tabel 41 diperoleh nilai sebesar $89 \%$.

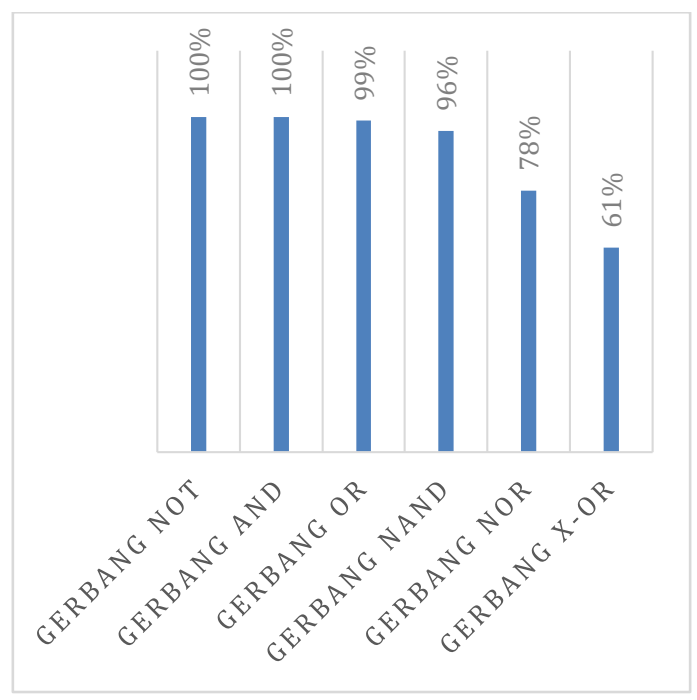

Gambar 7. Hasil keefektifan media

Persentase penilaian gerbang NOT total jawaban benar sebanyak 60 butir dengan hasil presentase sebesar $100 \%$, penilaian gerbang AND total jawaban benar sebanyak 120 butir dengan hasil presentase sebesar $100 \%$, penilaian gerbang OR total jawaban benar sebanyak 119 butir dengan hasil presentase sebesar $99 \%$, penilaian gerbang NAND total jawaban benar sebanyak 115 butir dengan hasil presentase sebesar 96\%, penilaian gerbang NOR total jawaban benar sebanyak 93 butir dengan hasil presentase sebesar $78 \%$ dan penilaian gerbang X-OR total jawaban benar sebanyak 73 butir dengan hasil presentase sebesar $61 \%$.

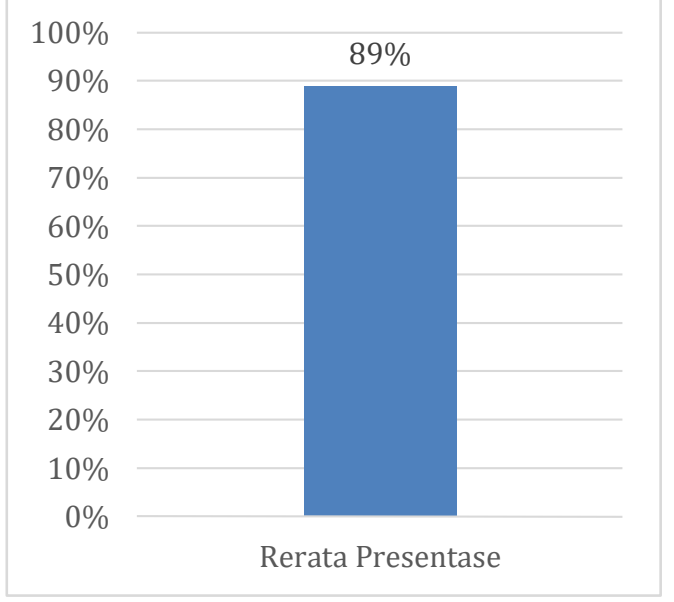

Gambar 8. Rerata kefektifan media

Hasil keseluruhan dari masingmasing evaluasi penilaian diperoleh rerata presentase sebesar $89 \%$. Berdasarkan data hasil pengujian didapatkan data kefektifan media pembelajaran sebesar $89 \%$, menurut Rating Scale pada Mardapi (2017) media pembelajaran ini dikategorikan baik yang berarti penggunaan media pembelajaran trainer teknik digital ini dapat dikategorikan efektif dalam pembelajaran.

Hasil penelitian yang dilakukan peneliti pada uji kefektivan media oleh siswa di SMKN 2 Kota Serang, dengan perolehan presentase sebesar $89 \%$. dengan hasil presentase tersebut dapat disimpulkan bahwa media pembelajaran trainer teknik digital dikategorikan 
efektif untuk digunakan sebagai sarana pembelajaran praktik teknik digital.

\section{KESIMPULAN}

Berdasarkan hasil penelitian pengembangan media tahap pertama yaitu studi pendahuluan ini meliputi beberapa tahapan seperti: (1) Studi Pustaka, (2) Survai Lapangan, dan (3) penyusunan produk awal. Tahap kedua yaitu, pengembangan produk ini meliputi beberapa tahap seperti: (1) Mendesain produk dilakukan dengan cara membuat hardware dan membuat jobsheet. (2) Pengujian Produk dalam penggunaan trainer. Tahap ketiga yaitu, uji coba produk pada tahap ini meliputi uji validasi kelayakan media oleh ahli materi dan ahli media.

Produk yang telah divalidasi dan dikatakan layak dengan evaluasi berupa hasil dari revisi produk kemudian di uji cobakan pada siswa. Tahap revisi dilakukan dengan uji kelayakan oleh ahli media dan ahli materi. Tahap selanjutnya adalah uji kelayakan media oleh siswa dan uji keefektifan media pembelajaran trainer kit teknik digital. Berdasarkan data hasil pengujian didapatkan data kelayakan media pembelajaran dengan perolehan rata-rata skor sebesar 87,7 terletak pada interval $\mathrm{x} \geq 75$. Hasil rata-rata skor tersebut dapat disimpulkan bahwa media pembelajaran trainer teknik digital dikategorikan sangat layak. Sedangkan Hasil keseluruhan dari masing-masing evaluasi penilaian diperoleh rerata presentase sebesar $89 \%$ dengan kategori baik yang berarti penggunaan media pembelajaran trainer teknik digital ini dapat dikategorikan efektif dalam pembelajaran.

\section{DAFTAR PUSTAKA}

Aggarwal, Er, H., Saini, R., \& Singh, S. $2015 . \quad$ "Digital Trainer." International Journal of IT,
Engineering and Applied Sciences Research (IJIEASR) 2124.

Emzir. 2011. Metodologi Penelitian Kualitatif Analisis Data. Jakarta: PT Raja Grafindo Persada Pusat.

Irwanto. 2020. Modul Metode Penelitian Pendidikan Kejuruan. Bahan Mengajar Program Studi Pendidikan Vokasional Teknik Elektro. Fakultas Keguruan dan Ilmu Pendidikan. Universitas Sultan Ageng Tirtayasa. SerangBanten.

Kemendikbud. 2016. Kemendikbud Terus Tingkatkan Pencapaian Program Prioritas Pemerintah. Oktober 24. http://kemendikbud.go.id/main/bl og/2016/10/24/kemendikbudterus-tingkatkan-pencapaianprogram-prioritas-pemerintah.

Kemenperin. 2017. Kemenperin Terbitkan Aturan Pendidikan Kejuruan Berbasis Industri. Januari 9. http://www.kemenperin.go.id/arti kel/17009/Kemenperin-

Terbitkan-Aturan-Pendidikan-

Kejuruan-Berbasis-Industri.

Mardapi, Djemari. 2017. Pengukuran,

Penilaian dan Evaluasi Pendidikan (Edisi Revisi). Yogyakarta: Parama Publishing.

Muti'ah. 2017. Pengembangan Media Pembelajaran Trainer dan Jobsheet yang Mendukung Pembelajaran PBL Pada Materi Elektronika Digital Di SMK. Skripsi.

Sudira, P. 2011. Kurikulum dan Pembelajaran Pendidikan dan Pelatihan Vokasi Menyongsong Skill Masa Depan. Makalah dipresentasikan pada Pengembangan Kurikulum. Bali: Politeknik Negeri Bali. 
Sudjana, N. 2015. Penilaian Hasil Proses Belajar Mengajar. Bandung: PT. Remaja Rosdakarya.

Sugiyono. 2011. Metode Penelitian Kuantitatif, Kualitatif, dan $R \& D$. Bandung: Alfabeta, CV.

Sukmadinata, N. S. 2012. Metode Penelitian Pendidikan. Bandung: PT. Remaja Rosdakarya.

Susanto, dkk. 2013. Media Pendidikan: Pengertian, Pengembangan, dan Pemanfaatannya. Jakarta: Rajawali Pers.

Sutikno, M. S. 2015. Belajar dan Pembelajaran, Prospect. Edisi Revisi ke-5. Bandung.

Wijaya, E.Y., Sudjimat, D.A, Nyoto, A. 2018. Transformasi Pendidikan Abad 21 Sebagai Tuntutan Pengembangan Sumber Daya Manusia Di Era Global. Volume 1: 266-267. 